\title{
PENGARUH PEMBERIAN DADIH DENGAN PERUBAHAN JUMLAH Lactobacillus fermentum PADA FESES IBU HAMIL
}

\author{
Ranne Balqis \\ STIKes Sumbar \\ Email:ranne.balqis14@gmail.com
}

\begin{abstract}
Pregnant women with adequate prebiotic consumption known having better immune function and also better pregnancy, depress the event of premature labor and preeclampsia event. This study conducted to find out the influence of dadih consumption to the change of the number of lactobacillus fermetum in pregnant women. This study was a experimental study with equivalent pre-post test with control group design. Population of this study was those who included in join research with Dr. dr. Andani Eka putra, MSc and Dr. Helmizar, SKM, M.Biomed. We take population from pregnant women in 10 PUSKESMAS in Agam District, West Sumatera, with sampling was done consecutively. Minimal total sample was 24 for each group. After observation at the beginning of study, intervention group was given 100cc dadih daily until second observation. Mean of colony in pregnant women before taking dadih was 3,713 CFU/mh and after was 4,580 log CFU/g ( $p=0.367)$. In control group, the number of colony at $1^{\text {st }}$ observation was 3,999 $\log C F U / g$ and 4,436 log CFU/g in 2 nd observation $(p=0.475)$. The changes in both group were compared and resulting in significantly different change $(p=0.022)$. There is no statistically significant influence of dadih consumption with the change in the number of lactobacillus fermentum in pregnant women. However, this study was found better change after observation in intervention group.
\end{abstract}

Keywords : dadih, probiotic, Lactobacillus fermentum, pregnant women

ABSTRAK

Wanita hamil yang mengkonsumsi prebiotic diketahui memiliki fungsi kekebalan tubuh dan kehamilan yang lebih baik, serta dapat menekan kejadian kelahiran prematur dan preeklampsia. Penelitian ini dilakukan untuk mengetahui pengaruh konsumsi dadih terhadap perubahan jumlah lactobacillus fermetum pada ibu hamil. Penelitian ini adalah penelitian eksperimental pre-post tes dengan desain kelompok kontrol. Populasi penelitian ini ibu hamil di 10 Puskesmas di Kabupaten Agam, Sumatera Barat, dengan pengambilan sampel dilakukan secara berurutan. Setelah pengamatan pada awal penelitian, kelompok intervensi diberikan dadih $100 \mathrm{cc}$ setiap hari sampai pengamatan kedua. Rerata koloni lactobacillus fermetum pada wanita hamil sebelum pemberian dadih adalah $3.713 \mathrm{CFU} /$ mh dan setelahnya $4.580 \log \mathrm{CFU} / \mathrm{g}(\mathrm{p}=0,367)$. Pada kelompok kontrol, jumlah koloni pada pengamatan pertama adalah $3.999 \log$ CFU / g dan $4.436 \log$ CFU / g dalam observasi kedua $(\mathrm{p}=0,475)$. Perubahan pada kedua kelompok dibandingkan dan menghasilkan perubahan yang sangat berbeda $(\mathrm{p}=0,022)$. Tidak ada pengaruh yang signifikan secara statistik dari konsumsi dadih dengan perubahan jumlah lactobacillus fermentum pada wanita hamil. Penelitian ini ditemukan perubahan yang lebih baik di kelompok intervensi.

Kata kunci : Dadih, Ibu Hamil Probiotic, Lactobacillus Fermentum 


\section{PENDAHULUAN}

Flora normal pada usus merupakan sebuah istilah yang merujuk pada organisme yang hidup pada sistem gastroinstenstinal manusia. Kolonisasi yang terbentuk pada saluran pencernaan terutama pada usus dapat berupa kelompok bakteri patogen maupun nonpatogen yang memiliki efek positif bagi tubuh manusia. Hubungan yang terjadi antara kelompok bakteri maupun inangnya adalah berupa perubahan bentuk energi dari makanan yang dimakan oleh manusia, namun tidak dapat diubah oleh enzim yang terdapat didalam sistem pencernaan. Diketahui bahwa beberapa bakteri memiliki kemampuan untuk menghasilkan senyawa bioaktif yang dapat membantu proses metabolisme tubuh, seperti perubahan molekul susu menjadi komponen laktosa dari sistem fermentasi yang di lakukan oleh bakteri asam laktat (BAL) (Sekirof dan Finlay, 2009).

Beberapa faktor yang dapat memengaruhi jumlah kolonisasi flora normal dalam usus seperti : genetik, penyakit, penggunaan antibiotik, pola makan, berat badan dan kehamilan (Taylor et al, 2017). Bakteri asam laktat dikenal sebagai bakteri probiotik. Kadar BAL yang di temukan pada tubuh Ibu baik pada kondisi normal ataupun pada masa kehamilan menunjukkan efek perbaikan metabolisme terutama dalam mengonversi gula menjadi bentuk lain seperti peningkatan asam laktat yang berguna dalam pembentukan Air Susu Ibu (ASI) (Yavuzdurmaz, 2007).

Bakteri asam laktat sendiri merupakan kelompok bakteri Grampositif yang tidak berspora dan dapat memfermentasikan karbohidrat untuk menghasilkan asam laktat. Berdasarkan taksonomi, terdapat sekitar 20 genus bakteri yang termasuk BAL. Beberapa BAL yang sering digunakan dalam pengolahan pangan adalah Aerococcus,
Bifidobacterium, Carnobacterium, Enterococcus,Lactobacillus, Lactococcus, Leuconostoc, Oenococcus, Pediococcus, Streptococcus, Tetragenococcus, Vagococcus, dan Weissella. Dalam pengolahan makanan, BAL dapat melindungi makanan dari pencemaran bakteri patogen, meningkatkan nutrisi, dan berpotensi memberikan dampak positif bagi kesehatan (Khalil dan Anwar, 2016).

Sebagian besar BAL dapat tumbuh sama baiknya di lingkungan yang memiliki dan tidak memiliki O2 (tidak sensitif terhadap $\mathrm{O} 2$ ), sehingga termasuk anaerob aerotoleran. Bakteri yang tergolong dalam BAL memiliki beberapa karakteristik tertentu yang meliputi: tidak memiliki porfirin dan sitokrom, katalase negatif, tidak melakukan fosforilasi transpor elektron, dan hanya mendapatkan energi dari fosforilasi substrat.

Bakteri asam laktat berpotensi memberikan dampak positif bagi kesehatan dan nutrisi manusia, beberapa di antaranya adalah meningkatkan nilai nutrisi makanan, mengontrol infeksi pada usus, meningkatkan pencernaan laktosa, mengendalikan beberapa tipe kanker, dan mengendalikan kadar kolesterol dalam darah. Sebagian keuntungan tersebut merupakan hasil dari pertumbuhan dan aksi bakteri selama pengolahan makanan, sedangkan sebagian lainnya hasil dari pertumbuhan beberapa BAL di dalam saluran usus saat mencerna makanan yang mengandung BAL sendiri.

Bakteri asam laktat dapat menghambat pertumbuhan bakteri lain dengan memproduksi protein yang disebut bakteriosin. Salah satu contoh bakteriosin yang dikenal luas adalah nisin, diproduksi oleh Lactobacillus lactis ssp. Nisin dapat menghambat pertumbuhan beberapa bakteri, yaitu Bacillus, Clostridium, Staphylococcus, dan Listeria. Senyawa bakteriosin yang diproduksi BAL dapat bermanfaat 
karena menghambat bakteri patogen yang dapat merusak makanan ataupun membahayakan kesehatan manusia, sehingga keamanan makanan lebih terjamin (Dugoua et al, 2009).

Dadih adalah produk susu kerbau fermentasi yang berasal dari Sumatera Barat yang merupakan bahan pangan tradisional (Surono et al, 2008). Dadih merupakan produk susu kerbau yang difermentasikan secara alami dalam wadah bambu pada suhu kamar selama 24 - 48 jam. Dadih biasanya disajikan dengan cara mencampurkannya dengan emping beras ketan merah yang sudah dipipihkan serta ditambah santan dan cairan gula merah. Dadih juga dapat dimakan dengan nasi dan lauk pauk (Rafiq, 2007).

Dari beberapa penelitian diketahui bahwa dadih mengandung BAL yang potensial sebagai probiotik. Bakteri probiotik yang terkandung dalam dadih ini merupakan Lactobacillus dan Bifidobacterium (Taufiq, 2004). BAL dan produk turunannya mampu mencegah timbulnya berbagai penyakit. Merupakan makanan yang baik untuk menambah stamina dan daya tahan tubuh, mencegah kanker usus, memperbaiki mikroflora intestinal, memperbaiki kembali kondisi usus setelah mendapat pengobatan antibiotik, mengobati diare yang disebabkan oleh antibiotik, virus dan bakteri, anti mutagen, anti karsinogenik dan efektif sebagai antivaginitis (Afriani, 2009).

Ibu hamil yang memiliki asupan probiotik yang baik diketahui memiliki fungsi imun yang lebih baik, hal ini sesuai dengan pernyataan oleh Wibowo et al, (2015) yang menemukan bahwa konsumsi probiotik selama masa kehamilan merupakan prilaku yang aman bagi kesehatan. Lebih lanjut pada penelitian ini juga menemukan bahwa Ibu dengan asupan probiotik teratur memiliki kehamilan yang lebih sehat, menekan angka kejadian bayi prematur dan juga dapat menurunkan prevalensi preeklamsi. Sedangkan penelitian yang dilakukan oleh Dottereud et al, (2010) menemukan bahwa pemberian probiotik pada Ibu hamil dan balita dapat menekan angka kejadian dermatitis atopi, namun tidak berpengaruh pada sensitisasi alergen.

Penelitian Khalil dan Anwar (2016) yang melakukan isolasi BAL pada susu dan yogurt menemukan bahwa dari genus Lactobasillus yang dominan adalah $L$. cellobiosus, $L$. delbrueckii, L. hilgardii, L. coryniformis subsp. coryniformis, $L$. salivarius, $L$. leichmanni and L. plantarum. Pada penelitian ini juga menemukan aktifitas dari bakteri ini di dalam tubuh mampu memberikan efek yang baik bagi tubuh terutama pada saluran pencernaan.

Sekirov dan Finlay (2009) melakukan penelitian tentang kolonisasi bakteri gastrointenstinal menemukan bahwa infeksi yang terjadi akibat bakteri patogen dapat di tekan dengan konsumsi probiotik. Pada penelitian ini menemukan bahwa BAL yang terkandung pada makanan probiotik dapat meningkatkan aktifitas imun dengan mengeluarkan modulator biologis yang bersifat bakteriosid, meningkatkan aktifitas makrofag dan maturasi sel $\mathrm{T}$ dan $\mathrm{B}$.

Oleh karena keberagaman penelitian yang di lakukan dan belum adanya identifikasi secara spesifik jumlah BAL pada feses Ibu hamil yang mengonsumsi dadih, maka peneliti tertarik untuk melakukan penelitian dengan judul "Pengaruh Pemberian Dadih dengan Perubahan Jumlah Lactobacillus fermentum pada Feses Ibu Hamil"

\section{METODE PENELITIAN}

Jenis penelitian ini adalah penelitian eksperimen semu (Quasi Eksperimen) dengan desain Equivalent pre-post test with control group design dimana dilakukan pengukuran terhadap subjek kelompok perlakuan dan kontrol 
sebelum dan sesudah perlakuan (Notoatmotjo, 2002). Penelitian ini adalah penelitian bersama yang dilakukan oleh Dr. dr. Andani Eka putra, MSc dan Dr. Helmizar, SKM, M.Biomed. Peneliti mengambil populasi ibu hamil di 10 Puskesmas di Dua Kecamatan (Baso dan Tilatang kamang), Kabupaten Agam, Sumatera Barat, karena sentra produksi dadih berada di salah satu Kecamatan ini dan dadih merupakan pangan yang tidak asing bagi masyarakat Agam dan sekitarnya. Sampel pada penelitian ini dipilih secara konsekutif. Sampel pada kelompok perlakuan diberikan dadih selama kehamilan berlangsung, sedangkan kelompok kontrol tidak diberi dadih selama kehamilan. Jumlah sampel minimal pada setiap kelompok adalah 12 orang.

Data diperoleh dengan beberapa tahapan
a. Peneliti terlebih dahulu menghubungi tiap ibu hamil untuk memberi penjelasan proses penelitian yang sedang peneliti lakukan.

b. Setelah mendapat persetujuan, peneliti meminta untuk mengumpulkan sampel awal pada kedua kelompok responden, selanjutnya kelompok perlakuan diberi dadih sebanyak 100cc setiap harinya, sementara kelompok kontrol tidak diberi dadih. Menginjak usia kehamilan aterm, Ibu kembali diminta untuk mengumpulkan sampel akhir dan memasukkannya kedalam tempat khusus yang telah disediakan peneliti.

c. Sampel yang telah didapat akan di lanjutkan dengan tahapan pemeriksaan menggunakan alat laboratorium.

d. Hasil pemeriksaan yang telah dilakukan merupakan data yang nantinya akan di pergunakan sebagai hasil yang akan di uji secara statistik.

\section{Cara pengambilan sampel}

Peneliti terlebih dahulu menghubungi tiap ibu hamil untuk memberi penjelasan proses penelitian yang sedang peneliti lakukan. Setelah mendapat persetujuan, peneliti meminta untuk mengumpulkan sampel awal pada kedua kelompok responden, selanjutnya kelompok perlakuan diberi dadih sebanyak 100cc setiap harinya, sementara kelompok kontrol tidak diberi dadih.

Menginjak usia kehamilan aterm, ibu kembali diminta untuk mengumpulkan sampel akhir dan memasukkannya kedalam tempat khusus yang telah disediakan peneliti. Sampel yang telah didapat akan di lanjutkan dengan tahapan pemeriksaan menggunakan alat laboratorium. Hasil pemeriksaan yang didapat nantinya akan di pergunakan sebagai hasil yang akan di uji secara statistik.

\section{Isolasi DNA dari spesimen (menggunakan Kit Promega)}

Sampel yang didapat langsung di masukkan kedalam tempat penyimpanan dengan suhu $-20^{\circ}$ hingga waktu akan digunakan. Timbang $200 \mathrm{mg}$ sampel, suspensi kedalam $9 \mathrm{ml}$ buffer C, Vortex selama 20 Detik. Saring dengan menggunakan kasa steril, Kemudaian Centrifuge dengan kecepatan $12.000 \mathrm{rpm}$ selama 10 Menit. Kemudian cuci pelet sebanyak tiga kali dengan larutan Buffer $C$, Vortex hingga homogen, Centrifuge kembali dengan kecepatan 60 rpm selama 3 Menit, ulangi hingga $3 x$, pengulangan ketiga lakukan pengadukan cairan dengan pelet hingga homogen. Suspensi larutan menggunakan Lisozym Digestion Buffer 200uL.

Prosedur dilakukan sesuai dengan protokol Kit Promega untuk bakteri Gram +. Buat suspensi dengan memasukkan $50 \mu \mathrm{L}$ EDTA kedalam sel. Masukkan Cell Lysis Solution kedalam suspensi sebanyak $120 \mu \mathrm{L}$, lakukan pengadukan dengan pipet untuk merobek dinding sel (lisis). Vortex sampai homogen, Inkubasi sampel pada suhu $37^{\circ} \mathrm{C}$ selama 30 Menit, Centrifuge 
selama 2 Menit dengan kecepatan $14.000 \mathrm{~g}$.

Buang supernatan, tambahkan $60 \mu \mathrm{L}$ Nukleat lysis, aduk sampai tersuspensi. Inkubasi pada suhu $80^{\circ} \mathrm{C}$ selama 5 menit untuk melisiskan sel, dinginkan sampai mencapai suhu ruangan. Masukkan $3 \mu \mathrm{L}$ RNAse Solution kemudian bolak balik tube 2-5x untuk mencampurkannya. Inkubasi pada suhu $37^{\circ} \mathrm{C}$ selama 20 menit, diamkan hingga mencapai suhu ruangan.

Masukkan $20 \quad \mu \mathrm{L} \quad$ Protein Precipitation Solution RNAse Treated Cell lysis, lalu Vortex dengan selama 20 Detik untuk mencampurkannya. Inkubasi sel dengan es selama 5 menit, Centrifuge $14.000 \mathrm{~g}$ selama 3 Menit. Siapkan Mikrotube baru, isi Isopropanol $600 \mu \mathrm{L}$ campurkan dengan cairan hasil Centrifuge tadi, pelet di buang, kemudian Vortex sampai terlihat bagian putih- putih, Centrifuge 14.000g selama 2 Menit.

Buang supernatan, serap sisa cairan yang masih tersisa dengan kasa steril, lalu tambahkan $600 \mu \mathrm{L}$ etanol $70 \%$ bolak balik Tube untuk mencuci Pelet, Centrifuge $14.000 \mathrm{~g}$ selama 2 Menit. Ambil cairan dengan menggunakan Micropipet (Hatihati jangan sampai terkena Pelet), usahakan cairan habis terserap, biarkan Pelet kering dengan cara buka Tube, lalu tutup dengan kassa steril, diamkan 10 Menit. Tambahkan $100 \mu \mathrm{L} \quad$ DNA Rehidration Solution, inkubasi selama 1 Jam pada suhu $65^{\circ} \mathrm{C}$, tiap 5- 10 Menit angkat Tube, ketuk-ketuk bagian dasarnya lalu lanjutkan inkubasi. Hasil isolasi DNA siap digunakan ke tahapan selanjutnya.

\section{Real Time PCR (Menggunakan Kit Bioline)}

Tahap real time PCR yaitu DNA feses (Template DNA) di Master mix dilakukan real time PCR dengan alat, selanjutnya dilakukan primer reverse sesuai dengan kondisi selanjutnya dilakukan elektroforesa untuk melihat berapa jumlah mikroflora bakteri tersebut sesuai dengan standar pada kurva PCR.
Primer yang digunakan untuk PCR kuantitatif dapat dilihat pada table 4.1. real time PCR dilakukan pada reaksi volume $10 \mu \mathrm{l}$, 96 well dan 480 siklus. PCR dilakukan dalam satu siklus prainkubasi pada suhu $94^{\circ} \mathrm{C}$ selama 15 detik, annealing pada suhu $55^{\circ} \mathrm{C}$ selama 15 detik, dan pada suhu $72^{\circ} \mathrm{C}$ selama 20 detik untuk perpanjangan. Kurva leleh dianalisis dengan pemanasan pada suhu berkisar dari $55-90^{\circ} \mathrm{C}$ pada tingkat $5^{\circ} \mathrm{C} / \mathrm{s}$.

\section{Kuantifikasi Bakteri}

Real time PCR atau Q-PCR menawarkan kemampuan untuk menganalisis data selama fase log-linear. Sebuah plot fluoresensi vs jumlah siklus menghasilkan bentuk kurva sigmoidal yang disebut kurva pertumbuhan. Untuk menganalisis Q-PCR, reaksi dari fase loglinear digunakan untuk menentukan ambang batas siklus (Cycle Threshold/CT) untuk masing-masing sampel. Untuk mendapatkan garis referensi nilai $\mathrm{Ct}$ dari sejumlah sampel untuk mengetahui jumlah bakteri yang ditentukan.

\section{HASIL DAN PEMBAHASAN Karakteristik Responden}

Subjek yang ada di Wilayah kerja Puskesmas di Kecamatan Baso dan Tilatang Kamang, Kabupaten Agam adalah ibu hamil dengan karakteristik dasar responden secara umum adalah ibu hamil dengan usia rata-rata 31 tahun pada kelompok perlakuan, 28 tahun pada kelompok kontrol dengan usia kehamilan rata-rata 14 - 15 Minggu, yang berjumlah 24 orang. Dari 24 orang tersebut 12 orang diberikan dadih selama masa kehamilan dan 12 orang lagi tidak diberikan dadih selama masa kehamilan. Selanjutnya dilakukan pemeriksaan terhadap sampel sebelum dan setelah perlakuan.

\section{Tabel 5.1 Karakteristik Responden} Karakteristik Responden Perlakuan Kontrol

Usia ibu, tahun (rerata \pm SD) $31.25 \pm 5.72 \quad 28.62 \pm 5.25$

Usia Kehamilan, tahun

$($ rerata \pm SD) $14.23 \pm 1.88 \quad 14.92 \pm 1.65$ 
Secara umum responden merasa senang dan antusias terhadap dadih karena responden sudah mengetahui manfaat dan kebaikan dari dadih tersebut setelah dijelaskan oleh peneliti.

\section{Uji Normalitas Data}

Setelah uji normalitas data dilakukan dengan uji KolmogorovSmirnov, maka didapatkan bahwa jumlah koloni L.fermentum dalam feses terdistribusi normal (Nilai $\mathrm{P}>0,05$ ). Selanjutnya untuk melihat pengaruh pemberian dadih dengan perubahan jumlah L. fermentum pada feses Ibu hamil digunakan uji T- Dependent (Parametrik).

Pengaruh Pemberian Dadih dengan

Perubahan Jumlah L.fermentum

Terhadap Responden yang

Mendapat Dadih (Perlakuan).

Penelitian ini dilakukan dengan mengambil sampel feses ibu hamil sebelum diberikan dadih, kemudian dilakukan pemeriksaan. Selanjutnya ibu hamil diberi 100cc dadih/Hari selama masa kehamilan dan pada akhir kehamilan sampel feses kembali diambil untuk diperiksa. Dari hasil penelitian menunjukkan bahwa rata-rata jumlah koloni pada ibu hamil sebelum mendapat dadih adalah $3.713 \log \mathrm{CFU} / \mathrm{g}(\log \mathrm{x}=$ $6 \times 10^{3}$ ), sedangkan jumlah koloni rata-rata setelah mengonsumsi dadih adalah 4.580 $\log \mathrm{CFU} / \mathrm{g}\left(\log \mathrm{x}=46 \times 10^{3}\right)$. Hasil uji statistik didapatkan nilai $\mathrm{P}=0.367$, secara statistik tidak terdapat pengaruh yang signifikan pemberian dadih dengan perubahan jumlah L.fermentum pada feses ibu hamil.

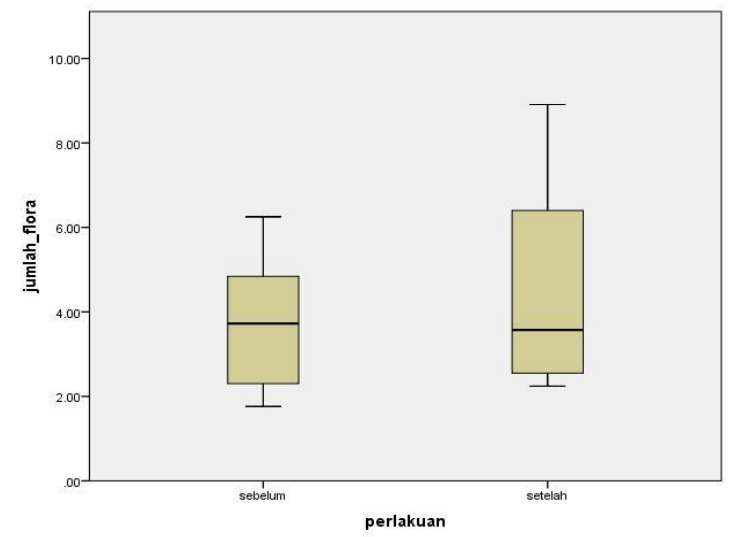

Tabel 1. Distribusi Rata-Rata Log Jumlah Koloni L.fermentum Terhadap Responden yang Mendapat Dadih (Perlakuan).

\begin{tabular}{llll}
\hline Kelompok & Sebelum & Sesudah & $P$-Value \\
& $(\log \mathrm{CFU} / \mathrm{g})$ & $(\log \mathrm{CFU} / \mathrm{g})$
\end{tabular}

$\begin{array}{llll}\text { Dadih } & 3.713 & 4.580 & 0,367 \\ \text { (Perlakuan) } & & & \end{array}$

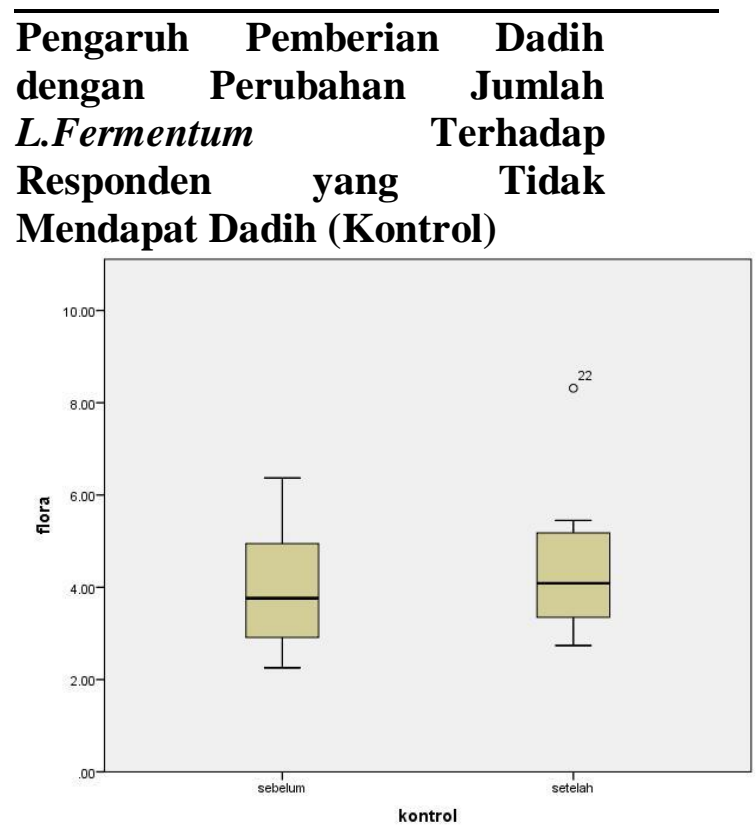

Penelitian ini dilakukan dengan pengambilan sampel pertama (awal kehamilan), kemudian dilakukan pemeriksaan. Selanjutnya pengambilan sampel kedua dilakukan pada akhir kehamilan. Dari hasil penelitian didapatkan bahwa rata-rata jumlah koloni pada ibu hamil yang tidak mengonsumsi dadih saat pengambilan sampel pertama (awal kehamilan) adalah $3.999 \log \mathrm{CFU} / \mathrm{g}$ $\left(\log \mathrm{x}=8 \times 10^{3}\right)$, sedangkan saat pengambilan sampel kedua (akhir kehamilan) rata-rata jumlah koloninya adalah $4.436 \log \mathrm{CFU} / \mathrm{g}\left(\log \mathrm{x}=24 \times 10^{3}\right)$. Hasil uji statistik didapatkan nilai $\mathrm{P}=$ 0,475, secara statistik tidak terdapat pengaruh yang signifikan terhadap perubahan jumlah L.fermentum pada feses ibu hamil sebelum dan setelah pengamatan. 
Tabel 2. Distribusi Rata-Rata Log Jumlah Koloni L.fermentum Terhadap Responden yang Tidak Mendapat Dadih (Kontrol).

\begin{tabular}{llll}
\hline Kelompok & $\begin{array}{l}\text { Sebelum } \\
(\log \text { CFU/g) }\end{array}$ & $\begin{array}{l}\text { Sesudah } \\
(\log \text { CFU/g) }\end{array}$ & $\begin{array}{l}\text { P-Value } \\
\end{array}$ \\
& & & 0, \\
& & 47 \\
Tidak dadih & 3.999 & 4.436 & 5 \\
(Kontrol) & & &
\end{tabular}

\section{Berdasarkan hasil penelitian} diatas maka didapatkan hasil bahwa secara statistik tidak terdapat pengaruh yang signifikan terhadap perubahan jumlah L.fermentum pada feses ibu hamil pada kedua kelompok responden. Namun dijumpai peningkatan rerata jumlah L.fermentum yang lebih jelas pada kelompok perlakuan.

Perubahan Jumlah L. fermentum Pada Kelompok Perlakuan \& Kontrol

Dari hasil penelitian didapatkan perubahan bahwa ibu hamil yang diberi dadih dan yang tidak diberi dadih diperoleh nilai $P$-value adalah 0,022 ( $p$ $=<0,05)$. Dengan demikian didapatkan ada perubahan yang signifikan rata-rata jumlah $L$. fermentum pada feses ibu hamil yang diberi dadih dan yang tidak diberi dadih. Dimana dijumpai peningkatan jumlah $L$. fermentum yang lebih bermakna pada kelompok perlakuan dari pada kelompok kontrol.

Tabel 3. Perubahan Mikroflora Intestin

\begin{tabular}{lllll}
\hline KelompokN & $\begin{array}{l}\text { Mean } \\
\text { Pre } \\
\text { (log } \\
\text { CFU/g) }\end{array}$ & $\begin{array}{l}\text { Mean } \\
\text { Post }\end{array}$ & $\begin{array}{l}\text { Selisih Value } \\
\text { (log } \\
\text { CFU/g) }\end{array}$ & $\begin{array}{l}\text { (log } \\
\text { CFU/g) }\end{array}$ \\
\hline Perlakuan 12 & 3.713 & 4.580 & 0.867 & 0,0 \\
& & & \multicolumn{2}{c}{$\begin{array}{l}22 \\
22\end{array}$} \\
Kontrol & 12 & 3.999 & 4.436 & 0.437 \\
\hline
\end{tabular}

Pengaruh Pemberian Dadih dengan Perubahan Jumlah L.fermentum Pada Feses Ibu Hamil
Rata-rata jumlah L. fermentum pada kelompok perlakuan sebelum diberi dadih adalah 3,713 $\log \mathrm{CFU} / \mathrm{g}\left(\log \mathrm{x}=6 \times 10^{3}\right)$, setelah diberi dadih 4,580 log CFU/g (log $\mathrm{x}=46 \times 10^{3}$ ) dan pada kelompok kontrol pada awal kehamilan adalah log 3,999 CFU/g $\left(\log x=8 \times 10^{3}\right)$ dan pada akhir kehamilan 4,436 $\log \mathrm{CFU} / \mathrm{g}(\log \mathrm{x}=$ $\left.24 \times 10^{3}\right)$. Artinya tidak terdapat pengaruh yang signifikan pemberian dadih terhadap jumlah $L$. fermentum pada feses ibu hamil. Hal ini tidak sejalan dengan penelitian yang dilakukan oleh Philip et al, 2009 yaitu efek probiotik dalam lumen saluran cerna adalah meningkatkan mikroflora dengan menjaga keseimbangan mikroflora dan menjaga kolonisasi.

Meskipun secara statistik tidak signifikan, hasil penelitian kami yang menunjukkan bahwa pemberian dadiah memperbesar jumlah L.fermentum pada feses ibu hamil, sejalan dengan penelitian Sekirov dan Finlay (2009) melakukan penelitian tentang kolonisasi bakteri gastrointenstinal menemukan bahwa infeksi yang terjadi akibat bakteri patogen dapat di tekan dengan konsumsi probiotik. Pada penelitian ini menemukan bahwa BAL yang terkandung pada makanan probiotik dapat meningkatkan aktifitas imun dengan mengeluarkan modulator biologis yang bersifat bakteriosid, meningkatkan aktifitas makrofag dan maturasi sel $\mathrm{T}$ dan $\mathrm{B}$.

\section{Probiotik Pada Ibu Hamil}

$\begin{array}{llr}\text { Probiotik } & \text { merupakan organisme } \\ \text { hidup yang } & \text { dapat memberikan } \\ \text { keuntungan } & \text { terhadap } & \text { kesehatan. } \\ \text { Keuntungan kepada host apabila }\end{array}$
dikonsumsi sebagai food suplemen. Bakteri probiotik dapat digunakan sebagai pelengkap atau suplemen makanan alternatif. Bakteri probiotik yang banyak dikenal termasuk kelompok BAL dan termasuk mikroorganisme yang aman bagi kesehatan. Lactobacillus merupakan bakteri Gram positif yang bersifat anaerob, berbentuk batang dan tidak 
bergerak dan paling banyak digunakan sebagai agen probiotik (Sumaryati, 2013).

Mikroflora saluran pencernaan merupakan bagian penting dalam dinding pertahanan usus. Komposisi awal dari mikroflora saluran pencernaan yang berkembang merupakan faktor penentu perkembangan fungsi pertahanan saluran pencernaan normal. Mikrobiota saluran pencernaan normal dapat mencegah pertumbuhan yang berlebihan dari bakteri patogen dalam saluran pencernaan (Harish, 2006).

Bakteri probiotik memiliki banyak manfaat untuk kesehatan manusia, diantaranya dalam sistem imunitas dimana membantu daya tahan tubuh dan melindungi tubuh dari berbagai macam infeksi, sistem pencernaan yang baik dimana mampu mencegah masuknya bakteri pathogen dan memelihara integritas usus terhadap mikroorganisme.

Dari beberapa penelitian diketahui bahwa dadih mengandung BAL yang potensial sebagai probiotik. Bakteri probiotik yang terkandung dalam dadih ini merupakan Lactobacillus dan Bifidobacterium (Taufiq, 2004). BAL dan produk turunannya mampu mencegah timbulnya berbagai penyakit. Merupakan makanan yang baik untuk menambah stamina dan daya tahan tubuh, mencegah kanker usus, memperbaiki mikroflora intestinal, memperbaiki kembali kondisi usus setelah mendapat pengobatan antibiotik, mengobati diare yang disebabkan oleh antibiotik, virus dan bakteri, anti mutagen, anti karsinogenik dan efektif sebagai antivaginitis (Afriani, 2009).

Adapun beberapa faktor yang dapat memengaruhi jumlah kolonisasi flora normal dalam usus seperti : genetik, penyakit, penggunaan antibiotik, pola makan, berat badan dan kehamilan (Taylor et al, 2017). BAL dikenal sebagai bakteri probiotik. Kadar BAL yang di temukan pada tubuh ibu baik pada kondisi normal ataupun pada masa kehamilan menunjukkan efek perbaikan metabolisme terutama dalam mengonversi gula menjadi bentuk lain seperti peningkatan asam laktat yang berguna dalam pembentukan Air Susu Ibu (ASI) (Yavuzdurmaz, 2007).

Ibu hamil yang memiliki asupan probiotik yang baik diketahui memiliki fungsi imun yang lebih baik, hal ini sesuai dengan pernyataan oleh Wibowo et al, (2015) yang menemukan bahwa konsumsi probiotik selama masa kehamilan merupakan prilaku yang aman bagi kesehatan. Lebih lanjut pada penelitian ini juga menemukan bahwa ibu dengan asupan probiotik teratur memiliki kehamilan yang lebih sehat, menekan angka kejadian bayi prematur dan juga dapat menurunkan prevalensi preeklamsi. Sedangkan penelitian yang dilakukan oleh Dottereud et al, (2010) menemukan bahwa pemberian probiotik pada ibu hamil dan balita dapat menekan angka kejadian dermatitis atopi, namun tidak berpengaruh pada sensitisasi alergen.

\section{SIMPULAN}

Dilihat dari hasil yang ditemukan pada penelitian ini, maka dapat diambil kesimpulan sebagai berikut :

1. Tidak terdapat pengaruh signifikan pemberian dadih terhadap jumlah $L$. fermentum pada feses ibu hamil.

2. Ditemukan perubahan jumlah $L$. fermentum yang lebih banyak pada kelompok perlakuan.

\section{SARAN}

1. Diperlukan penelitian lanjutan dengan luaran utamanya adalah penilaian secara objektif (klinis) mengenai manfaat pemberian dadih terhadap ibu hamil.

2. Diperlukan penelitian lanjutan dengan sampel yang lebih banyak untuk dapat melihat efek pemberian dadih secara lebih luas. 


\section{DAFTAR PUSTAKA}

1. AETNA. 2012. Healthy Pregnancy Handbook, the Beginning Right Maternity Program.

2. Afriani. $2009 . \quad$ Pengaruh Penggunaan Starter Bakteri Asam Laktat Lactobacillus plantarum dan Lactobacillus fermentum terhadapTotal Bakteri Asam Laktat, Kadar Asam dan Nilai pH Dadih Susu Sapi $J$ Ilmiah IlmuIlmuPeternakan 8(6): 279-285.

3. American College of Gastroenterology, 2006, Gastrointestinal Disorders in Pregnancy.

4. Bayitse R, 2015, Lactic Acid Production from Biomass: Prospect for Bioresidue Utilization in Ghana: Technological Review. International Journal of Applied Science and Technology; Vol. 5, No. 1.

5. Brownawell AM, Caers W, Gibson GR, Kendall CWC, Lewis KD. 2012, Prebiotics and the Health Benefits of Fiber: Current Regulatory Status, Future Research, and Goas. American Society for Nutrition; pp 962-975.

6. Bulut C. 2003, Isolation and Molecular Characterization of Lactic Acid Bacteria from Cheese. İzmir Institute of Technology.

7. Coelho LF, De Lima CJB, Rodovalho CM, Bernardo MP, Contiero J. 2011, Lactic Acid Production by New Lactobacillus Plantarum Lmism6 Grown In Molasses: Optimization of Medium Composition. Brazilian Journal of Chemical Engineering; Vol. 28, No. 01 , pp. $27-36$.

8. Cock LS, De Stouvenel AR. 2006, Lactic Acid Production By A Strain of Lactococcus Lactis Subs Lactis Isolated from Sugar Cane Plants. Electronic Journal of Biotechnology ; Vol.9 No.1.

9. Colehour AM, Meadow JF, Liebert MA, Cepon-Robins TJ, Gildner TE,
Urlacher SS, et al. 2014, Local Domestication of Lactic Acid Bacteria via Cassava Beer Fermentation. Peer Journal ; 2:e479.

10. Dottereud CK, Storre O, Johnsen R, Oien T. 2010, Probiotics in Pregnant Women to Prevent Allergic Disease : A Randomized, Double Blinded Trial. British Journal of Dermatology ; 163 ; 616623.

11. Dugoua JJ, Machado M, Zhu X, Chen X, Koren G, Einarson TR. 2009, Probiotic Safety in Pregnancy: A Systematic Review and Meta-analysis of Randomized Controlled Trials of Lactobacillus, Bifidobacterium and Saccharomyces spp. Journal of Obstetry \& Gynaecology ;31(6):542-552.

12. Erdogrul O, Erbilir F. 2006, Isolation and Characterization of Lactobacillus bulgaricus and Lactobacillus casei from Various Foods. Turkish Journal of Biology ; 39-44.

13. Family Health Services. 2016, Your Pregnancy Book. Department of Health of Hongkong.

14. Fijan S. 2014, Microorganisms with Claimed Probiotic Properties : An Overview of Recent Literature. International Journal of Environment Public Health ; 11, 4745-4767.

15. Gluckman P, Hanson M, Seng CY, Bardsley A. 2015, Prebiotics and Probiotics in Pregnancy and Breastfeeding. Oxford Medicine Online. Rutten N, Van der Gugten A, Uiterwaal C, Vlieger A, Rijkers G, Van der Ent K. Maternal Use of Probiotics During Pregnancy and Effects on Their Offspring's Health in An Unselected Population. European Journal of Pediatrics. 2016; 175:229-235.

16. Ikeda DM, Weinert Jr A, Chang KCS, McGinn JM, Miller SA, Keliihoomalu C, et al. 2013, Natural 
Farming : Lactic Acid Bacteria. College of Tropical Agriculture and Human Resources. University of Hawai'i at Manoa. Van De Guchte M, Penaud S, Grimaldi C, Barbe V, Bryson K, Nicolas P, et al. The Complete Genome Sequence of Lactobacillus Bulgaricus Reveals Extensive and Ongoing Reductive Evolution.

17. Imler PB, Wilbanks D. 2010, The Essential Guide to Getting Pregnant. Imler \& Banks Publishing.

18. Juodeikiene G, Bartkiene E, Viskelis P, Urbonaviciene D, Eidukonyte D, Bobinas C. 2011, Fermentation Proccess Using Lactid Acid Bacteria Producing Bacteriocins for Preservation \& Improving Functional Properties of Food Products. Kaunas University of Technology. Quinto EJ, Jimenez P, Caro I, Tejero J, Mateo J, Girbes T. Probiotic Lactic Acid Bacteria: A Review. Food and Nutrition Sciences. 2014 ; 5 ; 1765-1775.

19. Karovicova J, Kohajdova Z 2003, Lactic Acid Fermented Vegetable Juices. HORT Science. (4): 152-158.

20. Khalid K. 2011, An Overview of Lactid Acid Bacteria. International Journal of Biosciences ; $1 ; 1-13$.

21. Khalil I, Anwar N. 2016, Isolation, Identification and Characterization of Lactic Acid Bacteria from Milk and Yoghurts. Research \& Reviews: Journal of Food and Dairy Technology. 4 ; 3 ; 17-26. 